\title{
Transparency of government healthcare websites: a predictive model based on the main public administrations of Chile, Colombia, Ecuador, and Spain
}

\author{
Daniel Barredo-Ibáñez; Pedro Molina-Rodríguez-Navas; Vanessa Rodríguez-Breijo; \\ Narcisa Medranda-Morales
}

Nota: Este artículo se puede leer en español en:

https://revista.profesionaldelainformacion.com/index.php/EPI/article/view/86696

How to cite this article:

Barredo-Ibáñez, Daniel; Molina-Rodríguez-Navas, Pedro; Rodríguez-Breijo, Vanessa; Medranda-Morales, Narcisa (2022). "Transparency of government healthcare websites: a predictive model based on the main public administrations of Chile, Colombia, Ecuador, and Spain". Profesional de la información, v. 31, n. 1, e310104. https://doi.org/10.3145/epi.2022.ene.04

Manuscript received on $29^{\text {th }}$ September 2021 Accepted on $26^{\text {th }}$ October 2021
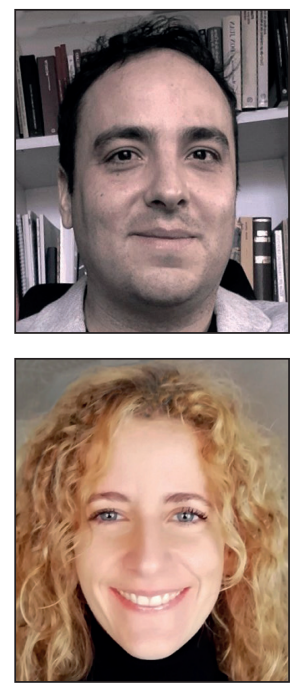

Daniel Barredo-Ibáñez

https://orcid.org/0000-0002-2259-0756

Universidad del Rosario

Escuela de Ciencias Humanas

Bogotá, Colombia

Fudan University

Shanghai, China

daniel.barredo@urosario.edu.co

\section{Vanessa Rodríguez-Breijo}

https://orcid.org/0000-0002-9749-8444

Universidad de La Laguna

Facultad de Ciencias Sociales y de la Comunicación

La Laguna (Tenerife), Spain

vrbreijo@ull.edu.es

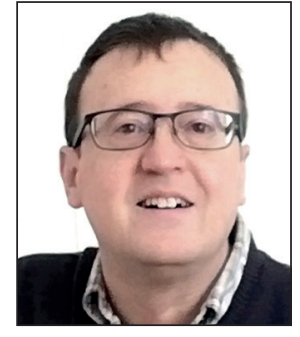

Pedro Molina-Rodríguez-Navas https://orcid.org/0000-0002-1586-881X

Universitat Autònoma de Barcelona, Departamento de Comunicación

Audiovisual y Publicidad

Profesor Serra Húnter

Bellaterra (Barcelona), Spain

pedro.molina@uab.cat

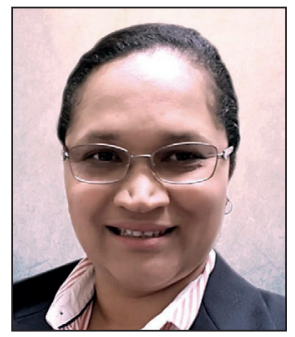

Narcisa Medranda-Morales

Universidad Politécnica Salesiana

Carrera de Comunicación

Quito, Ecuador

nmedranda@ups.edu.ec https://orcid.org/0000-0002-8191-9849

\begin{abstract}
Transparency and public accountability are two essential aspects of public administrations because they help to prevent possible cases of corruption and encourage citizen participation. In this sense, transparency is a communicative, not merely administrative or legal, process between public institutions and citizens. The main objective of this study is to identify predictive factors of transparency in government healthcare centers in Chile, Colombia, Ecuador, and Spain in 2021. To do this, we analyzed the websites of 64 public administrations from these countries. Content analysis was applied to assess the presence of 24 indicators on each website. The results for the studied cases reveal an association between the level of transparency and three factors: healthcare systems, internet access, and administration levels. We also identified a predictive factor that should be considered in future studies on the transparency of healthcare websites: the likelihood of decreased transparency was reduced by $91 \%$ for public healthcare systems (Ecuador and Spain) as opposed to mixed public -private healthcare systems (Chile and Colombia). We thereby conclude that the involvement of the State, at least in matters related to the healthcare field, favors greater access to information by the community, at the same time as providing greater social responsibility because of substantial communication of the activities carried out by these centers, as well as how and by whom.
\end{abstract}




\section{Keywords}

Transparency; Public administration; Accountability; Participation; Institutional communication; Organizational communication; Healthcare; Health information; Websites; Chile; Colombia; Ecuador; Spain.

Funding

This article is a result of the research activities of the Dirección de Investigación e Innovación of the Universidad del Rosario (Colombia), of the Laboratorio de Periodismo y Comunicación para la Ciudadanía Plural of the Universitat Autònoma de Barcelona (Spain) and of the Grupo de Investigación en Comunicación, Desarrollo y Política (Gicodepo) of the Universidad Politécnica Salesiana (Ecuador).

\section{Introduction}

Transparency and accountability are considered essential weapons in the fight against corruption and abuse of power. According to Vian (2020), in the healthcare field, such harmful practices include bribes, kickbacks, misappropriation of funds, and informal payments. Specifically, transparency is understood as access to information so that people know what is being done and planned by public institutions (García-García; Curto-Rodríguez, 2018), which currently use digital and network technologies to promote transparency (Roberts, 2006) as well as their relationship with citizens (Magallón-Rosa; Bolaños-Huertas; Anderica-Caffarena, 2017). Transparency is thus an imperative duty that cannot be avoided by the State, as well as a citizens' right that strengthens confidence in institutions as well as their reputation (Schmidthuber; Ingrams; Hilgers, 2020).

We understand transparency as a communicative, not merely administrative or legal, process between public institutions and citizens. These actors must therefore not only disclose how they manage resources but also explain their objectives, strategies, and procedures (Rivero-Menéndez; Mora-Agudo; Flores-Ureba, 2007), so that investment is consistent with electoral commitments, management, and the results achieved (Grimmelikhuijsen; Welch, 2012; García-García; Curto-Rodríguez, 2018), thereby supporting accountability. This is essential because the public sphere lacks indicators such as economic success as used in the private sector (Rivero-Menéndez; Mora-Agudo; Flores-Ureba, 2007). Therefore, management control and voting depend on information (Borge-Bravo, 2007; Alt; Lassen, 2006). On the other hand, Canel-Crespo and Luoma-aho (2019) affirm that changes in citizens' demands and expectations as well as new forms of communication or other technology will impact on the public sector, thereby continually maintaining and improving citizen engagement as well as providing other intangible benefits such as legitimacy or reputation, in order to carry out their public functions within a democratic framework.

Some authors, such as Etzioni (2010), have established a relationship between the cost of producing information and the usefulness of its publication, stating that the benefits of transparency are limited and that its cost is not justified by its usefulness. Fenster (2015) also believes that transparency theory uses conceptions that idealize its supposed benefits. Along the same lines, Alloa and Thöma (2018) introduce Critical Transparency Studies, considering that the term has yet to be clarified and that transparency is being used more as a strategy than to obtain results.

Although these criticisms indicate that rigorous analysis and more precise definitions are still necessary in this area, our perspective coincides with that of Schudson (2020) when he points out that transparency is an essential element but not a guarantee of good governance, and with Bertot, Jaeger and Grimes (2010), in the sense that it is a democratic right.

Transparency facilitates democratic participation (Bertot; Jaeger; Grimes, 2010), trust in governments (Schmidthuber; Ingrams; Hilgers, 2020), and the prevention of corruption (Bertot; Jaeger; Grimes, 2010; Anderson, 2009). As pointed out by Calvo-Gutiérrez (2013), it also contributes to improving the efficiency of public administrations. Openness of public management reduces irregularities and enables citizens to act as auditors (Casadesús-de-Mingo; Cerrillo-i-Martínez, 2018). However, one should remember that other elements must be added to transparency in order to achieve these purposes as a whole (Hernández-Bonivento, 2020), and to be effective it must become an institutional value or culture (Sagiv et al., 2017).

Despite the discussion in the previous paragraph, public media are often still used as partisan media (Del-Rey-Morató, 2007; Sanders; Canel-Crespo; Holtz-Bacha, 2011; Molina-Rodríguez-Navas et al., 2015), a reality that has various consequences, including a lack of trust in institutions, which is essential for democracy (Berganza-Conde; Arcila-Calderón; De-Miguel-Pascual, 2016). Rebolledo, Rodríguez-Virgili and Zamora-Medina (2015) consider that disaffection with democracy as a result of a lack of trust can also be addressed by transparency through access to data and sources. One study by Caamaño-Alegre et al. (2011) showed that, the higher the level of debt that a government inherits from its predecessor, the greater the interest in transparency. 
This lack of credibility of institutions also affects the entire media system, which uses statements from public administrations and their leaders as information sources. Such sources must thus be reliable and act as a barrier against false news, which can have serious consequences for public health, as highlighted by the coronavirus crisis. Vu and Saldaña (2021) state that the practice and professional routines of journalists should generate trust, and Humprecht (2020) studied the importance of fact-checkers. According to both studies, transparency in these sectors depends on the citation of sources. Public administrations must therefore become reliable sources as a barrier to false news, thus favoring the credibility of both institutions and the media.

Communication technologies are essential for the implementation of transparency by reducing publication costs and enabling continuous access online (Roberts, 2006). Thus, websites are essential for institutional legitimacy today, as well as an open relationship between administrations and citizens, which enables interaction (Van-Ruler, 2018; González-Limón; Rodríguez-Ramos, 2019; Magallón-Rosa; Bolaños-Huertas; Anderica-Caffarena, 2017), dialog, and an overall improvement in the quality of democracy (Borge-Bravo, 2007). It is also important to remark that technology provides the means for citizens to know how governments are acting at different scales and thus form their opinions (Manfredi-Sánchez, 2017) and participate in deliberative processes (Uvalle-Berrones, 2007). However, Gandía, Marrahí, and Huguet (2016) affirm that interactive web tools are more decorative than useful. This explains the proliferation of organizations that use technology to monitor government activity, highlighting the importance attached to institutional transparency (Skaržauskienè; Mačiulienè, 2020).

However, although transparency may facilitate citizens' access to information, using both fixed and mobile devices (Garriga-Portolà, 2011; Pina; Torres; Royo, 2010), one should not forget that not all administrations in a given country will have sufficient resources to achieve complete and effective communication (Beltrán-Orenes; Martínez-Pastor, 2016; Gértrudix; Gertrudis-Casado; Álvarez-García, 2016).

Other work has established the difference between information published because of a legal obligation and that intended to promote participation (Santos; Galindo; Rover, 2019). In this regard, García-García and Curto-Rodríguez (2018; 2019) highlight the agency theory, which describes how governments seek to reduce informational asymmetry to enhance participation. However, the same authors also propose the neo-institutional theory, which explains the publication of public information with the aim of improving reputation, which is why one can speak of "sincere transparency" versus "apparent transparency" and of "open washing," i.e., the publication of irrelevant information in order to appear transparent. As stated by Sanders, Canel-Crespo, and Holtz-Bacha (2011), the professionalization of communication, even in the national governments of Germany, Spain, and the UK, applies rules that differentiate it from partisan communication but not in a systematic fashion. Francescutti and Saperas (2015) warn that institutional communication offices mainly seek to improve public image. Of course, studies reveal that in non-democratic contexts, information posted on government websites offers a favorable perspective on government activity.

The general aim of this paper is to identify predictive factors of transparency of government healthcare centers in Chile, Colombia, Ecuador, and Spain in 2021. A previous study by Charvel et al. (2018) compared the priorities of the healthcare systems of Brazil, Costa Rica, Chile, and Mexico and assessed whether legal instruments included transparency and other factors to achieve fair and accountable procedures. That study concluded that information was neither easy to access nor up to date. Our first specific aim here is to compare the main associations between three factors related to this context: the type of healthcare model, access to the internet, and the level or scale of the administrations composing the sample. Moreover, we studied the influence of these factors on the concept of transparency of such webpages. Before discussing our methodological approach, we present two theoretical axes that may be significant to understand the differences between countries: transparency in the healthcare field and the characteristics of the Chilean, Colombian, Ecuadorean, and Spanish healthcare systems.

We next present the theoretical framework, focused on transparency related to the healthcare field. We also describe the characteristics of the healthcare systems of each of the studied countries, whose context is essential when carrying out this empirical study. We then describe the hypothesis and the methodology that define the design. We then present and discuss the results of the study.

\section{Theoretical framework}

\subsection{Transparency in the healthcare field}

In comparison with transparency in other areas of government, work on citizen access to healthcare management information in the four studied countries is sparse. However, the administrations of these countries carry out normative and oversight actions on the availability of healthcare information.

In Chile, the Consejo para la Transparencia (Transparency Council) has audited the transparency of various organizations since 2014, performing oversight reports on transparency that have been applied to SEREMIs (Secretarías Regionales 
Ministeriales de la Salud or Regional Health Ministry Secretariats, abbreviated to SEREMI in Spanish), self-managed hospitals, or healthcare lobbying, although not in continuous manner:

https://www.consejotransparencia.cl/informes/fiscalizacion

Other studies have described the significant role of transparency in improving certain healthcare practices, such as problem-solving (Riego-Ramírez, 2019), or have defined the value of transparency of institutional websites and social media during health emergencies, when the health of a community must be preserved during a disaster (Díaz, 2019). Also, studies have been performed on the right to universal access to information, such as an analysis of the website of the Servicio Nacional de la Discapacidad (National Disability Service), which identified factors hindering full access to information by some communities (Binimelis-Espinoza; Veechi-Llanquile, 2018).

In the case of Colombia, since there is no general healthcare information system (Patiño, 2013), several independent or poorly interconnected systems have been created among private healthcare providers and public institutions (Bernal-Acevedo; Forero-Camacho, 2011). The cited authors also highlight issues associated with the lack of a single healthcare information platform or

In comparison with transparency in other areas of government, work on citizen access to healthcare management information in the four studied countries is sparse global mechanism, such as the lack of connection or even an incompatibility between public and private services, as also suggested by Orduña-Ortegón (2014). However, there are some examples at the municipal level that indicate an increasingly greater need to communicate data, including on healthcare, by public administrations. Bogota, the capital city of Colombia, has one of the most interesting open data platforms in the country, which is supported by the municipality: https://datosabiertos.bogota.gov.co

When last accessed (10 May 2021), users of this institutional webpage could search 1,476 datasets from 60 entities, of which 33 datasets were specifically related to healthcare. This open healthcare data strategy has been applied by other large Colombian cities such as Medellín:

https://geomedellin-m-medellin.opendata.arcgis.com

and Cali:

http://datos.cali.gov.co

According to Abusleme (2020), this type of open data system has been applied in Colombia since 2011, with the support of a normative framework, following recommendations from international institutions such as the World Bank and the Organisation for Economic Co-operation and Development (OECD). However, Abusleme's results also suggested that these repositories may contain data that lack more detailed elaboration or interpretation, thus hindering their interpretation by citizens or the media.

In Ecuador, the Ministerio de Salud Pública (Ministry of Public Health) has published the Estatuto Orgánico de Gestión Organizacional por Procesos (Organic Statute of Organizational Management by Processes), which establishes the responsibilities of decentralized government levels, including regional coordination and district administrations (Ministerio de Salud Pública, 2016).

In 2019, the same Ministry approved the creation of a Transparency Committee responsible for the monitoring and enforcement of the Ley Orgánica de Transparencia y Acceso a la Información Pública (Organic Transparency and Public Information Access Act) enacted on 18 May 2004, at both the central as well as decentralized, regional and district levels. The purpose of this committee was to ensure compliance with transparency laws by collecting, verifying, and analyzing published information, as stated in ministerial resolution no. MSP-DNGA-SG-10-2019-0736. Ecuador is divided into regions, provinces, cantons, and districts (Vargas-Arias, 2019). Decentralized municipal autonomous governments follow a project drafted by the Ministerio de Salud Pública (2016), the Proyecto Municipios Saludables en el Ecuador (Project for Healthy Municipalities in Ecuador). A certification model is used to analyze the different healthcare dimensions of the population. One of the components of this model is the participation of citizens in public management as well as public accountability to citizens, where transparency regarding public information is clearly needed.

In Spain, Act 19/2013 on transparency, access to public information, and good governance does not describe any particular actions to be applied in the healthcare field, as also seen in the laws on transparency approved by various Spanish autonomous communities, although some of these are even more ambitious than the national one. However, this act can be used as a framework to define the obligations of any administration regarding the disclosure of data about their management. For this reason, its provisions apply to every healthcare organization operating within the national territory.

Autonomous administrations manage most community-related services, such as healthcare, education, and social services. Moreover, according to data from the Ministerio de Hacienda y Función Pública (Ministry of Treasury and Public Administration), autonomous communities managed around 35\% of Spain's total public expenditure in 2017, making them a key partner for accountability (García-García; Curto-Rodríguez, 2019). Most communities thus have their own transparency legislation that regulates their obligations regarding the publication of information about the areas they manage, including healthcare among others. 
Among the tools used to evaluate this information, the most important are the transparency portals for each administrative field. In particular, the portal of the Administración General del Estado (General State Administration) includes a healthcare section:

https://transparencia.gob.es/transparencia/transparencia_Home/index/Mas/nformacion/Informes-de-interes/Salud.html

as does the portal of the Ministerio de Hacienda y Función Pública (Ministry of Treasury and Public Function), which has developed its Health Care Information System together with the autonomous communities since 2004 http://inclasns.msssi.es/main.html

as a complement to the transparency portals. However, public institutions have not produced an up-to-date study on the availability of healthcare information.

\subsection{The healthcare systems of Chile, Colombia, Ecuador, and Spain}

The Chilean Constitution of 1980 established a healthcare system that reflects the importance of private as opposed to public management. Section 19, subsection 9, of this Constitution sets forth that the government must protect "free and equal access to actions aimed at the promotion, protection, and recovery of individuals' health, as well as their rehabilitation" and "coordinate and control actions related to health care." The same text states that

"each person shall be entitled to choose his/her healthcare system, whether public or private,"

which is why the government must

"ensure the provision of healthcare services, regardless of whether they are provided by public or by private institutions, in the manner and conditions stated by law, which could establish mandatory costs."

In 2014, a Presidential Counseling Commission concluded that this system based on competence and freedom of choice should focus on the right to healthcare and on the principles of solidarity and equity (Cid; Uthoff, 2017). However, subsequent studies still found that the population is segregated and criticized the fact that healthcare is mostly seen as a commodity service (Rotarou; Sakellariou, 2017; Goyenechea, 2019).

As in the case of Chile, the Colombian Constitution of 1991 describes "physical integrity" as a fundamental right (Section 44) and holds the government responsible for the provision of healthcare services (Sections 49 and 366). Act 100 of 23 December 1993 created the Integrated Social Security System, access to which is guaranteed to all citizens by the State (Section 3), also entrusting its monitoring to the State and its provision to public or private institutions (Section 4). However, this system has been modified in order to decentralize service provision. In this regard, Act 1122 of 2007 sets forth provisions regulating requests from the Instituciones Prestadoras de Servicios de Salud (Health Services Institutions, abbreviated to IPS in Spanish) and Entidades Promotoras de Salud (Health Promoting Entities, abbreviated to EPS in Spanish). Despite being mostly dominated by private companies, Colombia has a Superintendencia Nacional de Salud (National Superintendence of Public Health) that becomes involved in case of conflict between the EPS and its users. Later, in 2011, Act 1438 set forth the principles governing the system, among which transparency is one of the most important (Section 3.14), being based on healthcare provision mechanisms, policies, and the relationship between the operators. Based on the Constitution of 1991 and the normative context described above, the General Social Security System of Colombia was developed in 1993, being a combination of public and private administrations and based on contributing affiliates and being funded by taxes paid by all citizens (Agudelo-Calderón et al., 2011). Meanwhile, Suárez-Rozo et al. (2017) describe how users are dissatisfied with the nonuniform quality of the healthcare system and the financial instability of the EPS.

Section 12 of the Constitution of Ecuador of 2018 sets forth that healthcare is a right that must be guaranteed by the government. Moreover, this constitution states that the provision of healthcare services is governed by the principles of equity, universality, solidarity, interculturality, quality, efficiency, efficacy, precaution, and bioethics, focusing on gender and age. Meanwhile, the Ley Orgánica de Salud (Organic Health Act), approved in 2006, states that the highest health authority in Ecuador is the Ministry of Public Health, which is responsible for applying, monitoring, and enforcing compliance with the law.

Lucio, Villacrés, and Henríquez (2011) report that the Ecuadorean healthcare system includes both the public and private sectors. The former provides services to $51 \%$ of the population and includes the Instituto Ecuatoriano de Seguridad Social (Ecuadorian Social Security Institute), Instituto de Seguridad Social de las Fuerzas Armadas (Armed Forces Social Security Institute, abbreviated to ISSFA in Spanish), Instituto de Seguridad Social de la Policía Nacional (National Police Social Security System, abbreviated to ISSPOL in Spanish), the programs of the Ministerio de Inclusión Económica y Social (Ministry of Economic and Social Inclusion, abbreviated to MIES in Spanish), and municipal programs. The private sector provides services to $49 \%$ of the population through private physicians or clinics. This sector is gaining importance due to the difficulties associated with the provision of healthcare services by the public sector (Molina-Guzmán, 2018). There is also a nonprofit private sector, which includes independent civil organizations as well as social service organizations (Buitrón-Vega; Gea-Izquierdo; García-Oquendo, 2016).

Finally, the Spanish National Health System offers universal coverage and is financed through taxes and copayments of drugs and healthcare products by patients. Copayments can be reduced or removed based on each patient's community 
or treatment. There are also private insurance agencies and healthcare centers, but unlike Chile and Colombia, healthcare is mostly provided by the public network. The 17 autonomous communities of Spain are responsible for the provision and promotion of healthcare. The central government is responsible for legislating and coordinating the cooperation between institutions and agents. The body in charge of this is the Ministerio de Sanidad, Consumo y Bienestar Social (Ministry of Health, Consumer Affairs, and Social Welfare) (Carnicero; Rojas, 2010). At a local level, the Ley General de Sanidad (General Health Act) 14/1986 of April 25 sets forth that

"the regulations of the Autonomous Communities on the organization of their respective healthcare services shaII consider the responsibilities and competencies of the provinces, municipalities, and any other intracommunity Territorial Administration, pursuant to the statutes of Autonomy, Local Regime Act, and this Act."

Consequently, competencies at the local level are defined by the healthcare regulations of each autonomous community.

The main objective of transparency laws in general is to enable citizen access to information, not only for the mere fact of knowing but also to influence public management, thus requiring that such information be published with the characteristics necessary to make it understandable (Medranda-Morales, 2017).

The legal frameworks regulating the healthcare systems of Spain, Colombia, Chile, and Ecuador must address the demands of citizens, who must know what and how public health funds are spent. In this regard, García-Altés and Argimon (2016) argue that data corresponding to expenditure in this sector must be made available so that citizens, social movements, researchers, and all interested stakeholders can access complete and detailed information that allows them to express their opinions and become involved in public policies. Human Rights Watch (2020) has established that governments are responsible for providing the information necessary for the protection and promotion of rights, including the right to health.

\section{Hypotheses and methodology}

\subsection{Hypotheses}

To establish the hypotheses of this work, we chose three aspects: the type of healthcare system (mixed or public), internet access, and different administration levels or scales (local, regional, and municipal). The first of these (healthcare systems) has not been considered in previous studies, despite being an important question related to transparency in the healthcare field. Besides this novelty, it is also an interesting factor because it can help to explain the influence of context on the implementation of transparency.

As indicated in the "Introduction," the benefits of the second factor, i.e., internet access, in terms of transparency include an enhancement of institutional reputation (Kim; Lee, 2012). Greater availability of information can result in improved accountability, which will also enhance social participation. However, as such communication processes through internet tools and platforms focus on the previous year, difficulties in accessing them can result in a gap among users and less interest from public administrations in presenting relevant news and data through these channels. In the context of communication studies, the use of technological has been a key element influencing both transparency and open government (Cullier; Piotrowski, 2009; Jaeger; Bertot, 2010). It is widely believed that there is a relation between the availability of information and the empowerment of citizens (Da-Cruz; Marques, 2014), as technology can also help facilitate the comprehension of health-related content, user interactivity, and information collation (Cameron, 2004; Bertot; Jaeger; Grimes, 2012). Institutional use of technology enables the development of active users or prosumers (Aparici; García-Marín, 2018), who have a strong ability to contribute to the development of public opinion.

Regarding the third factor, the different levels or scales of an administration are another aspect that has not been well investigated in previous literature. Studies on transparency are scarce or associated with one particular aspect of administration. Therefore, governments from the national to local level use communication to present themselves as efficient and reliable to their electors (Grimmelikhuijsen; Welch, 2012). However, one should not ignore the difficulties that some administrations face in this regard, especially those with less resources or personnel available (Beltrán-Orenes; Martínez-Pastor, 2016; Gértrudix; Gertrudis-Casado; Álvarez-Martínez, 2016).

The cultural similarities among the four studied countries should also be highlighted, since their languages, predominant religions, and cultural imaginaries are similar. Overall, some evident differences are also seen. Broadly speaking, one of these differences arises from the general media system, that is, the media systems related to the public administrations included in our sample. In this regard, the Spanish journalistic culture is framed within the "polarized pluralist model" (Oller-Alonso; Barredo-Ibáñez, 2013), according to which there is a strong connection between mass media and political organizations. On the other hand, Chile, Colombia, and Ecuador are associated with the so-called "intermediate journalism culture," which according to the cited study, is characterized by political volatility, precarious working conditions for journalists, heritage and gaps extending from European colonialism, and political systems that are typically presidential republics.

In addition to the above-mentioned differences, which are mostly related to the media context, there are three other important differences that provide the basis for this research and which are related to the three hypotheses guiding our 
methodological approach: (1) Chile (Goyenechea, 2019) and Colombia (Agudelo et al., 2011) have mixed, public-private healthcare systems, whereas Ecuador (Ministerio de Salud Pública, 2016) and Spain (García-García; Curto-Rodríguez, 2019) have public healthcare systems, that is, operated and managed by the State. Based on this difference, our first hypothesis ( $\mathrm{H} 1)$ is established as follows: The type of healthcare system affects the level of transparency implemented on the websites of the healthcare divisions of the studied countries.

The second difference relates to internet access and, specifically, the technological gap or differences regarding access to the internet among the studied countries. In this regard, around $72 \%$ of users are connected to the internet in South America, while this percentage rises to 93\% in Western Europe (We are Social, 2021). Based on these regional averages, Chile and Spain present structural similarities, with 8 and 9 of every 10 Chilean or Spanish citizens being connected to the internet (Table 1).

Table 1. Structural data on Chile, Colombia, Ecuador, and Spain (2020)

\begin{tabular}{|l|c|c|c|}
\hline Variable & Chile & Colombia & Ecuador \\
\hline Total population (millions) & 19.03 & 50.61 & 7.75 \\
\hline Urban population & $88 \%$ & $81 \%$ & $55 \%$ \\
\hline \% of mobile phone connection in the population & $138 \%$ & $119 \%$ & $67 \%$ \\
\hline Internet access (millions of users) & 15.67 & 35 & 4.54 \\
\hline Internet access & $82 \%$ & $69 \%$ & $59 \%$ \\
\hline GDP per capita (USD) in 2020 & $13,231.70$ & $5,332.80$ & $5,600.40$ \\
\hline
\end{tabular}

Source: We Are Social (2020a; 2020b) and World Bank (2020).

Conversely, as shown in Table 1, 6 to 7 among every 10 Ecuadorian or Colombian citizens, respectively, have access to the internet. These results reveal that these two countries share a common gap. From this perspective, we propose the second hypothesis (H2): Internet access influences the levels of transparency implemented by the websites of the healthcare divisions of the studied countries. Comparison of World Bank (2020) data reveals greater economic development in Spain, as its GDP per capita is higher than the sum of the GDPs of the other three countries. Moreover, this greater wealth could be used to establish more transparent practices and products on the websites of health administrations.

The third difference is related to the levels or scales of the administrations. It seems logical to suggest that factors such as budgets and organization levels or processes will impact on the transparency management of the websites. Moreover, healthcare management is sometimes delegated to territorial bodies. In Chile, healthcare is delegated to the Secretarías Regionales Ministeriales de la Salud (SEREMI), whereas in Colombia, independent systems are developed within departments or even municipalities (Bernal-Acevedo; Forero-Camacho, 2011). Ecuador operates a system of territorial decentralization (Vargas-Arias, 2019), while in Spain, healthcare is mostly delegated to the autonomous communities (García-García; Curto-Rodríguez, 2019). We therefore define the third hypothesis (H3) as: The levels or scales of administrations influence the levels of transparency implemented by the websites of the healthcare divisions of the studied countries.

To define our methodological framework, we apply the Infoparticipa methodology (Molina-Rodríguez-Navas; Simelio-Solà; Corcoy-Rius, 2017; Molina-Rodríguez-Navas et al., 2015), which has been used in Spain to assess the transparency of local public institutions, adapting it to an assessment of the transparency of healthcare management by the different administrative levels studied.

\subsection{Methodology}

This is a correlational, nonexperimental study using data extracted in a cross-sectional manner. It is based on a line of research first developed by the Infoparticipa project that, as explained by Molina-Rodríguez-Navas, Simelio-Solà, and Corcoy-Rius (2017), assesses the concept of transparency of different Spanish institutions. The Infoparticipa project started in 2012, led by Amparo Moreno Sardà and the research team at the Laboratory of Journalism and Communication for Plural Citizenship of the Universitat Autònoma de Barcelona (Moreno-Sardá; Molina-Rodríguez-Navas; Corcoy-Rius, 2013; Moreno-Sardá; Molina-Rodríguez-Navas; Simelio-Solà, 2017). The development of the methodology, its operating platform, and related publications can be found via the Inforparticipa Map:

http://www.infoparticipa.com

Later, this team was expanded through a network of various Spanish universities, which are listed on the project website: https://www.infoparticipa.com/index/home/5

Through this collaborative work over recent years, several transparency evaluations have been carried out in Spanish municipalities in each autonomous community, in some cases on more than one occasion. In Catalonia, where the project started, a transparency evaluation has been carried out in 948 municipalities since 2013, including more recently also the websites of the provincial and county governments. Based on the original project carried out in Spain, some adaptations to other contexts have also been published, e.g., for Ecuadorean or Colombian administrations (Molina-Rodríguez-Navas; Medranda-Morales, 2018; Muñoz-Lalinde; Molina-Rodríguez-Navas, 2020). 
The content analysis technique was selected to address the purposes and hypothesis of this study because of the importance of obtaining data directly from primary sources, i.e., the analyzed websites. This technique can help to quantify a collection of observed analysis units (Masud et al., 2019). As indicated in the cited work, content analysis allows an examination of a variety of resources, such as texts, images, or videos. In this study, content analysis was essentially understood from an observation perspective (Barredo-Ibáñez, 2015). This means that the encoded features were collected by observing the websites of the selected public administrations.

To construct the analysis sheet used by the research team, we considered the legislation in each country, at both the national and regional level, in order to consider the specificities of each case and thereby compare them using a common instrument. Overall, the analysis sheet was obtained by a contextual adaptation of the Infoparticipa project (Molina-Rodríguez-Navas et al., 2015; Molina-Rodríguez-Navas; Simelio-Solà; Corcoy-Rius, 2017). To achieve this contextual adaptation, various control variables were considered for each country, including the legislative framework and previous theoretical results, among others. Then, the research team codified five cases for each country to confirm the quality of the instrument. After this step, we included 24 indicators, which were used to measure transparency in terms of the personnel or basic functions of each institution (indicators 1 to 6 ), the transparency in terms of institutional resources or data (indicators 7 to 19), and the transparency in terms of accessibility and participation (indicators 20 to 24).

The 24 indicators were measured from February to March of 2021 using dichotomous questions $(0=$ no; $1=$ yes $)$. A positive answer was entered when data were included in the portal, but not when the link on a website took users to another website. The sample was selected by considering relevance and pertinence criteria. Overall, we selected 64 study cases, with 16 per country included in the sample. This selection was performed by applying a nonrandom quota sampling method according to the following criteria: the ministry of health of each country was included, as well as the five autonomous communities, prefectures, or departments with the largest populations within these contexts, and the 10 most populous municipalities in each country. The following cases were studied: Ministerio de Salud (Chile), Ministerio de Salud y Protección Social (Colombia), Ministerio de Salud (Ecuador), and Ministerio de Sanidad, Consumo y Bienestar Social (Spain). In terms of autonomous communities, prefectures, or departments, were included the ones listed in Table 2.

Table 3 shows the municipalities included.

Table 2. Prefectures, departments or autonomous communities included in this study

\begin{tabular}{|c|c|c|c|}
\hline Chilean Seremis & Colombian departments & Ecuadorian prefectures & $\begin{array}{l}\text { Spanish autonomous commu- } \\
\text { nities }\end{array}$ \\
\hline Biobío & Antioquia & Azuay & Andalucía \\
\hline La Araucania & Atlántico & Cotopaxi & Cataluña \\
\hline Maule & Cundinamarca & Guayas & Comunidad Valenciana \\
\hline Región Metropolitana & Santander & Manabí & Galicia \\
\hline Valparaíso & Valle del Cauca & Pichincha & Madrid \\
\hline
\end{tabular}

Table 3. Municipalities included in this study

\begin{tabular}{|c|c|c|c|}
\hline Chile & Colombia & Ecuador & Spain \\
\hline Antofagasta & Barranquilla & Ambato & Barcelona \\
\hline La Florida & Bello & Cuenca & Bilbao \\
\hline Las Condes & Bogotá & Esmeraldas & Las Palmas de GC \\
\hline Maipú & Bucaramanga & Guayaquil & Madrid \\
\hline Puente Alto & Cali & Ibarra & Málaga \\
\hline San Bernardo & Cartagena & Machala & Murcia \\
\hline Santiago & Cúcuta & Naranjal & Palma de Mallorca \\
\hline Temuco & Medellín & Portoviejo & Sevilla \\
\hline Valparaíso & Soacha & Quito & Valencia \\
\hline Viña del Mar & Soledad & Riobamba & Zaragoza \\
\hline
\end{tabular}

Note that, as this study analyzed data from a nonrandom sampling method, the results cannot be generalized.

The three hypotheses are related to three independent variables, identified based on previous literature. The first variable was used to analyze the influence of the type of healthcare system on the concept of transparency implemented. As each country has a specific legal framework, it can be assumed that different practices will derive from them to construct a local imaginary. The healthcare systems of both Chile and Colombia are led by private management, as established by their constitutions of 1980 and 1991, respectively. Meanwhile, the healthcare systems of Ecuador and Spain are governed by the Constitution of Ecuador of 2018 and the acts and norms approved by each autonomous community and set by the General Health Act 14/1986 of April 25, respectively. 
The second variable is applied to explore the link between transparency and internet access. Although some authors argue that websites are fundamental to promote greater social participation (Van-Ruler, 2018; Magallón-Rosa; Bolaños-Huertas; Anderica-Caffarena, 2017), internet access can result in a gap, especially considering the digital context of the studied countries. in this regard, Ecuador and Colombia have nonuniform internet access, as a large part of the population is still focused on offline products. The third variable addresses the relation between transparency and the levels or scales of administrations. In this sense, technologies can enable greater social participation within different institutions (Manfredi, 2017), and authors such as Calvo (2013) have stated that transparency improves the procedures of public administrations. However, as described in the theoretical section, despite the benefits of transparency, many administrations do not have sufficient resources to develop better communication practices, as also explained by Gértrudix, Gertrudis, and Álvarez (2016) and Beltrán-Orenes, and Martínez-Pastor (2016).

According to the presentation above, the three studied factors can influence the implementation of transparency. Of course, there are other factors that could also be included in such an analysis, including the political system (Grimmelikhuijsen; Welch, 2012) or economic situation (Rivero; Mora; Flores, 2007), among others. However, this study focuses on three specific variables (healthcare system, internet access, and administration levels), as these are the main variables related to the proposed hypotheses. The three variables were created synthetically as dummy variables. The first two variables, i.e., healthcare systems and internet access, were recorded as dummy variables based on a nominal variable with a single option ("Country"), thus grouping data according to the country of origin among the four studied herein. In the case of healthcare systems, the dichotomous options included: $0=$ mixed healthcare system (Chile and Colombia) and 1 = public healthcare system (Ecuador and Spain). For the internet access variable, the following dichotomous answers were created: $0=$ low to moderate internet access (Colombia and Ecuador) and $1=$ high internet access (Chile and Spain). Then, based on the nominal and single-option variable for the type of administration, a dummy variable for administration levels or scales was created, according to which the 40 municipalities were recodified with a 0 and the ministries or regions with a 1. In all cases, the Kuder-Richardson coefficient (20) yielded highly acceptable values between 0.5 and 1 (Betancourt; Caviedes, 2018): 0.847 for healthcare systems, 0.816 for internet access, and 0.825 for administration levels or scales. All statistics were calculated using IBM SPSS Statistics version 25.

\section{Results}

\subsection{Descriptive analysis and associations between transparency and the proposed factors}

To describe the overall situation with regard to the proposed factors in each country, we start from Table 4. These descriptive statistics reveal higher transparency indicators among the countries with public versus private healthcare systems. For 19 of the 24 indicators, we found more information on the websites of the public healthcare systems. For such systems, 9 out of 10 analyzed websites tended to incorporate the annual budget $(94 \%, n=30)$, a button or section called "Transparency" focusing mostly on transparency data $(94 \%, n=30)$, information about budget execution and annual accounting $(91 \%, n=29)$, the salary of the head of the institution $(91 \%, n=29)$, the salaries of senior personnel $(91 \%, n=$ $29)$, and the ratio between operating staff and managers $(90 \%, n=28)$. In the case of the studied institutions in the mixed systems, we only found high values for the following indicators: information about the functions of the bodies/organizations $(75 \%, n=24)$, the publication of job offers or tender opportunities $(69 \%, n=22)$, the presence of an organizational chart with the names and/or functions of the senior management $(54 \%, n=19)$, the ability to download data provided by the institution in a reusable format $(34 \%, n=11)$, and the existence of a strategy to improve accessibility $(28 \%, n=9)$.

Considering the internet access variable, we found more information in 12 indicators for health administrations located in societies with a digital gap (Colombia and Ecuador) compared with institutions in countries with advanced implementation of the internet (Chile and Spain). In both types of countries, two indicators presented a draw: the publication of the institutional agenda of the head of the institution (medium access $=13 \%, n=4$; high access $=13 \%, n=4$ ) and the existence of a button or section called "transparency" on the websites (medium access $=84 \%, n=27$; high access $=84 \%$, $n=27$ ). In the countries with medium internet access, 8 or 9 out of 10 indicators were identified, including the publication of the annual budget $(97 \%, n=31)$, information about annual and multiannual plans or programs $(94 \%, n=30)$, and information about the rules developed $(84 \%, n=27)$. In the countries with high Internet access, we noted a major presence of job offers or tender opportunities $(75 \%, n=24)$, the publication of an organizational chart with the names and/or functions of the senior management $(59 \%, n=19)$, and the executed contracts $(56 \%, n=18)$, among others.

The ministries or regions tended to incorporate more indicators of transparency, according to the current analysis. Overall, we found that 13 out of the 24 indicators showed that they published more information than the municipalities. Between 7 and 8 of the 10 ministries or regional health administration websites provided information about annual and multiannual plans and programs $(88 \%, n=21)$, information about the rules developed and applied by the basic organic structure $(75 \%, n=$ 18 ), and information about the functions of the organs/
Considering the internet access variable, we found more information in 12 indicators for health administrations located in societies with a digital gap (Colombia and Ecuador) compared with institutions in countries with advanced implementation of the internet (Chile and Spain) 
Table 4. Descriptive statistics on the transparency of health administration websites in Chile, Colombia, Ecuador, and Spain (2021)

\begin{tabular}{|c|c|c|c|c|c|c|c|c|c|c|c|c|}
\hline & \multicolumn{4}{|c|}{ Health system } & \multicolumn{4}{|c|}{ Internet access } & \multicolumn{4}{|c|}{$\begin{array}{l}\text { Administration levels } \\
\text { or scales }\end{array}$} \\
\hline & \multicolumn{2}{|c|}{ Mixed } & \multicolumn{2}{|c|}{ Public } & \multicolumn{2}{|c|}{ Medium } & \multicolumn{2}{|c|}{ High } & \multicolumn{2}{|c|}{$\begin{array}{l}\text { Ministries } \\
\text { or regions }\end{array}$} & \multicolumn{2}{|c|}{$\begin{array}{l}\text { Municipa- } \\
\text { lities }\end{array}$} \\
\hline & $N$ & $\%$ & $N$ & $\%$ & $N$ & $\%$ & $N$ & $\%$ & $N$ & $\%$ & $N$ & $\%$ \\
\hline Is the résumé of the head of the institution published? & 9 & 28 & 24 & 75 & 20 & 63 & 13 & 41 & 15 & 63 & 18 & 45 \\
\hline Is the salary of the head of the institution published? & 6 & 19 & 29 & 91 & 20 & 63 & 15 & 47 & 12 & 50 & 23 & 58 \\
\hline Is the asset statement of the head of the institution published? & 3 & 9 & 16 & 50 & 5 & 16 & 14 & 44 & 8 & 33 & 11 & 28 \\
\hline $\begin{array}{l}\text { Is the institutional agenda of the head of the institution } \\
\text { published? }\end{array}$ & 0 & 0 & 8 & 25 & 4 & 13 & 4 & 13 & 2 & 8 & 6 & 15 \\
\hline Are the résumés of related senior positions published? & 11 & 22 & 11 & 34 & 3 & 9 & 15 & 47 & 10 & 42 & 8 & 20 \\
\hline Are the salaries of senior positions published? & 6 & 19 & 29 & 91 & 19 & 59 & 16 & 50 & 12 & 50 & 23 & 58 \\
\hline Is the ratio between operating staff managers published? & 11 & 34 & 28 & 90 & 24 & 75 & 15 & 48 & 14 & 58 & 25 & 64 \\
\hline Are job offers or public tender opportunities published? & 22 & 69 & 20 & 63 & 18 & 56 & 24 & 75 & 14 & 58 & 28 & 70 \\
\hline $\begin{array}{l}\text { Is there an organizational chart with the names and/or func- } \\
\text { tions of the upper management? }\end{array}$ & 19 & 54 & 15 & 47 & 15 & 47 & 19 & 59 & 10 & 42 & 24 & 60 \\
\hline $\begin{array}{l}\text { Is there information about the rules developed and applied } \\
\text { by the basic organic structure? }\end{array}$ & 19 & 59 & 26 & 81 & 27 & 84 & 18 & 56 & 18 & 75 & 27 & 68 \\
\hline $\begin{array}{l}\text { Is there information about the functions of these organs/ } \\
\text { organizations? }\end{array}$ & 24 & 75 & 13 & 41 & 21 & 66 & 16 & 50 & 17 & 71 & 20 & 50 \\
\hline $\begin{array}{l}\text { Is there information about annual and multiannual plans } \\
\text { and programs? }\end{array}$ & 25 & 78 & 26 & 81 & 30 & 94 & 21 & 66 & 21 & 88 & 30 & 75 \\
\hline Is a citizens' charter published? & 0 & 0 & 24 & 77 & 15 & 47 & 9 & 29 & 10 & 42 & 14 & 36 \\
\hline Is the annual budget published? & 24 & 75 & 30 & 94 & 31 & 97 & 23 & 72 & 19 & 79 & 35 & 88 \\
\hline $\begin{array}{l}\text { Is there information about budget execution and annual } \\
\text { accounting? }\end{array}$ & 23 & 72 & 29 & 91 & 30 & 94 & 22 & 69 & 18 & 75 & 34 & 85 \\
\hline $\begin{array}{l}\text { Is there information about the management and quality of } \\
\text { healthcare services? }\end{array}$ & 10 & 31 & 13 & 42 & 9 & 29 & 14 & 44 & 12 & 52 & 11 & 28 \\
\hline Are executed contracts published? & 7 & 22 & 25 & 78 & 14 & 44 & 18 & 56 & 11 & 46 & 21 & 53 \\
\hline Are executed agreements published? & 4 & 13 & 20 & 65 & 10 & 31 & 14 & 45 & 10 & 42 & 14 & 36 \\
\hline Is there information about received grants? & 12 & 38 & 26 & 81 & 22 & 69 & 16 & 50 & 12 & 50 & 26 & 65 \\
\hline $\begin{array}{l}\text { Is there information about the cost of institutional adverti- } \\
\text { sing campaigns in communication media? }\end{array}$ & 3 & 9 & 19 & 59 & 19 & 59 & 3 & 9 & 9 & 38 & 13 & 33 \\
\hline $\begin{array}{l}\text { Is there information about the characteristics of institutional } \\
\text { advertising campaigns in communication media? }\end{array}$ & 3 & 9 & 9 & 28 & 2 & 6 & 10 & 31 & 10 & 42 & 2 & 5 \\
\hline $\begin{array}{l}\text { Is it possible to download data given by the institution in a } \\
\text { reusable format? }\end{array}$ & 11 & 34 & 10 & 31 & 9 & 28 & 12 & 38 & 9 & 38 & 12 & 30 \\
\hline $\begin{array}{l}\text { Does the website have a button or section called "transpa- } \\
\text { rency" or anything of the sort? }\end{array}$ & 24 & 75 & 30 & 94 & 27 & 84 & 27 & 84 & 17 & 71 & 37 & 93 \\
\hline $\begin{array}{l}\text { Is there some kind of strategy on the website to favor acces- } \\
\text { sibility by ethnic minorities or nationalities? }\end{array}$ & 9 & 28 & 8 & 25 & 5 & 16 & 12 & 38 & 10 & 42 & 7 & 18 \\
\hline
\end{tabular}

organizations $(71 \%, n=17)$. The municipalities showed greater implementation a button or section called "transparency" $(93 \%, n=37)$, the publication of the annual budget $(88 \%, n=35)$, and the information about budget execution and annual accounting $(85 \%, n=34)$, among others.

However, it is also important to determine the extent to which there is an association between the factors and indicators. Table 5 thus presents the associations between the 24 sample variables and the three proposed factors. Since all the study variables are nominal and dichotomous, a chi-squared test for association was performed. To characterize the strength of each association, the phi coefficient is reported for significant cases. This is a coefficient for $2 \times 2$ tables (two columns by two rows) that represents the strength of the association as it approaches \pm 1 . 
Table 5. The associations between the proposed factors and the studied healthcare webpages in Chile, Colombia, Ecuador, and Spain (2021)

\begin{tabular}{|c|c|c|c|c|c|c|c|c|c|c|c|c|}
\hline & \multicolumn{4}{|c|}{ Health system } & \multicolumn{4}{|c|}{ Internet access } & \multicolumn{4}{|c|}{$\begin{array}{l}\text { Administration levels or } \\
\text { scales }\end{array}$} \\
\hline & $N$ & $\chi^{2}$ & GI & $\varphi$ & $\mathbf{N}$ & $\chi^{2}$ & Gl & $\varphi$ & $\mathbf{N}$ & $\chi^{2}$ & Gl & $\varphi$ \\
\hline Is the résumé of the head of the institution published? & 64 & $14.076^{*}$ & 1 & 0.469 & 64 & 3.065 & 1 & - & 64 & 1.839 & 1 & - \\
\hline Is the salary of the head of the institution published? & 64 & $33.356^{*}$ & 1 & 0.722 & 64 & 1.576 & 1 & - & 64 & 0.340 & 1 & - \\
\hline $\begin{array}{l}\text { Is the asset statement of the head of the institution } \\
\text { published? }\end{array}$ & 64 & $12.650^{*}$ & 1 & 0.445 & 64 & $6.063^{*}$ & 1 & 0.308 & 64 & 0.245 & 1 & - \\
\hline $\begin{array}{l}\text { Is the institutional agenda of the head of the institu- } \\
\text { tion published? }\end{array}$ & 64 & $9.143^{*}$ & 1 & 0.378 & 64 & 0.000 & 1 & - & 64 & 0.610 & 1 & - \\
\hline $\begin{array}{l}\text { Are the résumés of associated senior positions } \\
\text { published? }\end{array}$ & 64 & 1.237 & 1 & - & 64 & $11.130^{*}$ & 1 & 0.417 & 64 & 3.483 & 1 & - \\
\hline Are the salaries of senior positions published? & 64 & $33.356^{*}$ & 1 & 0.722 & 64 & 0.567 & 1 & - & 64 & 0.340 & 1 & - \\
\hline $\begin{array}{l}\text { Is the ratio between operating staff and manage- } \\
\text { ment positions published? }\end{array}$ & 63 & $20.900^{*}$ & 1 & 0.576 & 63 & $4.729 *$ & 1 & -0.274 & 63 & 0.210 & 1 & - \\
\hline Are job offers or tender opportunities published? & 64 & 0.277 & 1 & - & 64 & 2.494 & 1 & - & 64 & 0.905 & 1 & - \\
\hline $\begin{array}{l}\text { Is there an organizational chart with the names and/ } \\
\text { or functions of the highest authorities? }\end{array}$ & 64 & 1.004 & 1 & - & 64 & 1.004 & 1 & - & 64 & 2.025 & 1 & - \\
\hline $\begin{array}{l}\text { Is there information about the rules developed and } \\
\text { applied by the basic organic structure? }\end{array}$ & 64 & $3.668^{*}$ & 1 & 0.239 & 64 & $6.063^{*}$ & 1 & -0.308 & 64 & 0.404 & 1 & - \\
\hline $\begin{array}{l}\text { Is there information about the functions of these } \\
\text { organs/organizations? }\end{array}$ & 64 & $7.752^{*}$ & 1 & -0.348 & 64 & 1.602 & 1 & - & 64 & 2.669 & 1 & - \\
\hline $\begin{array}{l}\text { Is there information about annual and multiannual } \\
\text { plans and programs? }\end{array}$ & 64 & 0.097 & 1 & - & 64 & $7.819 *$ & 1 & -0.350 & 64 & 1.448 & 1 & - \\
\hline Is a citizens' charter published? & 63 & $40.020^{*}$ & 1 & 0.797 & 63 & 2.126 & 1 & - & 63 & 0.210 & 1 & - \\
\hline Is the annual budget published? & 64 & $4.267^{*}$ & 1 & 0.258 & 64 & $7.585^{*}$ & 1 & -0.344 & 64 & 0.790 & 1 & - \\
\hline $\begin{array}{l}\text { Is there information about budget execution and } \\
\text { annual accounting? }\end{array}$ & 64 & $3.692^{*}$ & 1 & 0.240 & 64 & $6.564^{*}$ & 1 & -0.320 & 64 & 0.321 & 1 & . \\
\hline $\begin{array}{l}\text { Is there information about management and the } \\
\text { quality of healthcare services? }\end{array}$ & 63 & 0.776 & 1 & - & 63 & 1.471 & 1 & - & 63 & $0.383^{*}$ & 1 & 0.247 \\
\hline Are executed contracts published? & 64 & $20.250^{*}$ & 1 & 0.563 & 64 & 1.000 & 1 & - & 64 & 0.267 & 1 & - \\
\hline Are executed agreements published? & 63 & $18.066^{*}$ & 1 & 0.535 & 63 & 1.292 & 1 & - & 63 & 0.210 & 1 & - \\
\hline Is there information about received grants? & 64 & $12.696^{*}$ & 1 & 0.445 & 64 & 2.332 & 1 & - & 64 & 1.399 & 1 & - \\
\hline $\begin{array}{l}\text { Is there information about the cost of institutional } \\
\text { advertising campaigns in communication media? }\end{array}$ & 64 & $17.732^{*}$ & 1 & 0.526 & 64 & $17.732 *$ & 1 & -0.526 & 64 & 0.166 & 1 & - \\
\hline $\begin{array}{l}\text { Is there information about the characteristics of } \\
\text { institutional advertising campaigns in communica- } \\
\text { tion media? }\end{array}$ & 64 & $3.692^{*}$ & 1 & 0.240 & 64 & $6.564^{*}$ & 1 & 0.320 & 64 & $13.238^{*}$ & 1 & 0.455 \\
\hline $\begin{array}{l}\text { Is it possible to download data given by the institu- } \\
\text { tion in a reusable format? }\end{array}$ & 64 & 0.071 & 1 & - & 64 & 0.638 & 1 & - & 64 & 0.383 & 1 & - \\
\hline $\begin{array}{l}\text { Does the website have a button or section called } \\
\text { "transparency" or anything of the sort? }\end{array}$ & 64 & $4.267^{*}$ & 1 & 0.258 & 64 & 0.000 & 1 & - & 64 & $5.341^{*}$ & 1 & -0.289 \\
\hline $\begin{array}{l}\text { Is there some kind of strategy on the website to favor } \\
\text { the accessibility of ethnic groups or nationalities? }\end{array}$ & 64 & 0.080 & 1 & - & 64 & $3.925^{*}$ & 1 & 0.248 & 64 & $4.491^{*}$ & 1 & -0.265 \\
\hline
\end{tabular}

$* p<0.05$

Among the three factors proposed herein, the one with the highest number of associations was health care systems (17 $\chi^{2}$ associations), followed by Internet access (10 $\chi^{2}$ associations) and administration levels or scales, with barely 4 $\chi^{2}$ associations. In the case of healthcare systems, we found an association with the publication of the director's salary $\left[\chi^{2}(1, N=64)=33.356, \varphi=.722, p<.05\right]$ as well as the publication of the salaries of senior management $\left[\chi^{2}(1, N=64)\right.$ $=33.356, \varphi=.722, p<.05]$. Thus, economic data about the salaries of the administrators of an institution was more frequently found in public than mixed public-private healthcare systems. An association was also found between the publication of the director's asset statement and healthcare systems $\left[\chi^{2}(1, N=64)=12.650, \varphi=.445, p<.05\right]$ as well as internet access $\left[\chi^{2}(1, N=64)=6.063, \varphi=.308, p<.05\right]$; that is, this feature was more frequently found in countries with public healthcare systems and internet access. In contrast, the publication of the annual budget and of budget execution and additional accounts occurred more frequently in countries with public healthcare systems $\left[\chi^{2}(1, N=64)=4.267, \varphi=\right.$ $.258, p<.05$ and $\chi^{2}(1, N=64)=3.692, \varphi=.240, p<.05$, respectively], and in those with low or moderate internet access 
$\left[\chi^{2}(1, N=64)=7.585, \varphi=-.344, p<.05\right.$ and $\left.\chi^{2}(1, N=64)=6.564, \varphi=-.320, p<.05\right]$. This was also observed regarding the publication of advertising campaign costs, which was more often found in countries with mixed systems $\left[\chi^{2}(1, N=\right.$ $64)=17.732, \varphi=-.526, p<.05]$ as well as in countries with low or moderate internet access $\left[\chi^{2}(1, N=64)=17.732, \varphi=\right.$ $-.526, p<.05]$. It is important to note that transparency regarding the group of economic indicators is one of the most widely implemented, as they can affect the control of information, especially during electoral campaigns (Borge-Bravo, 2007; Alt; Lassen, 2006).

Meanwhile, we also found an association both the publication of the director's résumé $\left[\chi^{2}(1, N=64)=14.076, \varphi=.469\right.$, $p<.05]$ and of the director's institutional agenda $\left[\chi^{2}(1, N=64)=9.143, \varphi=.378, p<.05\right]$ and healthcare systems, being more frequent in public healthcare systems. Likewise, publication of the agreements made with other institutions, especially contracts $\left[\chi^{2}(1, N=64)=20.250, \varphi=.563, p<.05\right]$, signed agreements $\left[\chi^{2}(1, N=63)=18.066, \varphi=.535, p<.05\right]$, and grants received $\left[\chi^{2}(1, N=64)=12.696, \varphi=.445, p<.05\right]$, occurred more frequently in public healthcare systems. In this sense, transparency regarding staff and hiring is relevant for public healthcare systems, as citizens are considered to be potential auditors (Schudson, 2020).

Regarding transparency on the basic functions of the institution, in general, citizens should be informed about the principal functions and management of each institution (García-García; Curto-Rodríguez, 2018). However, we found an association between healthcare systems and information about the functions of these bodies/organisms $\left[\chi^{2}(1, N=64)=\right.$ 7.752, $\varphi=-.348, p<.05]$, but a negative association with the publication of information about annual and multiannual plans and programs $\left[\chi^{2}(1, N=64)=7.819, \varphi=-.350, p<.05\right]$, which was more frequent in mixed healthcare systems. It is reported that transparency on staff and hiring can contribute to the prevention of corruption (Etzioni, 2010) and reinforce the links between society and the institution (Magallón-Rosa; Bolaños-Huertas; Anderica-Caffarena, 2017). The publication of a citizens' charter is also more frequent in public healthcare systems $\left[\chi^{2}(1, N=63)=40.020, \varphi=.797, p<\right.$ .05], maybe because this is a central element of good governance (Schudson, 2020) as well as a right of citizens (Bertot; Jaeger; Grimes, 2010).

In the case of internet access, a correlation was detected with the publication of the résumé of senior management $\left[\chi^{2}(1, N=64)=11.130, \varphi=.417, p<.05\right]$, especially in countries with high levels of internet access. The publication of the ratio between operating staff and management was found to be positively related to healthcare systems $\left[\chi^{2}(1, N\right.$ $=64)=20.900, \varphi=.576, p<.05]$ and internet access $\left[\chi^{2}(1, N=64)=4.729, \varphi=-.274, p<.05\right]$, being more frequent in countries with public healthcare systems and those with limited Internet access for a significant part of their population, despite literature recommendations that transparency should be considered imperative not only for the State but also for citizens (Schmidthuber; Ingrams; Hilgers, 2020). Moreover, information about the rules developed by the institution and the application of its organic structure is essentially associated with public healthcare systems $\left[\chi^{2}(1, N=64)=3.668\right.$, $\varphi=.239, p<.05]$ as well as with low or moderate internet access $\left[\chi^{2}(1, N=64)=6.063, \varphi=-.308, p<.05\right]$.

The administration levels or scales factor was mainly associated with the publication of data related to the management and quality of healthcare services $\left[\chi^{2}(1, N=63)=.383, \varphi=.247, p<.05\right]$, which was more frequent for ministries or regions or autonomous communities than municipalities. Among the three aspects studied, one of the items with the highest occurrence was publication of the characteristics of institutional advertising campaigns in the media, which was frequent in public healthcare systems $\left[\chi^{2}(1, N=64)=3.692, \varphi=.240, p<.05\right]$, countries with high internet access $\left[\chi^{2}(1\right.$, $N=64)=6.564, \varphi=.320, p<.05]$, and ministries or regional healthcare areas $\left[\chi^{2}(1, N=64)=13.238, \varphi=.455, p<.05\right]$. Both public healthcare systems $\left[\chi^{2}(1, N=64)=4.267, \varphi=.258, p<.05\right]$ and ministries and regional healthcare areas $\left[\chi^{2}(1, N=64)=5.341, \varphi=.289, p<.05\right]$ tended to centralize all their transparency indicators under a single tab or section within the website, called "transparency" or similar. Online websites should implement the concept of personalized transparency, providing public healthcare organizations with the opportunity to establish greater citizen interaction (Del-Rey-Morató, 2007; Molina-Rodríguez-Navas et al., 2015). However, overall, the existence of any type of web strategy to increase accessibility for ethnic minorities or peoples of a different nationality was more frequent in countries with high internet access $\left[\chi^{2}(1, N=64)=3.925, \varphi=.248, p<.05\right]$ and on the websites of ministries or regional healthcare areas $\left[\chi^{2}(1, N=64)=4.491, \varphi=-.265, p<.05\right]$.

\subsection{Binary logistic regression model: predictive factors of transparency on the websites of the studied healthcare systems}

Having confirmed the associations of the three proposed factors, we developed a synthetic and dichotomous index $(0=$ less transparency; 1 = more transparency) by adding the scores of the 24 dichotomous variables studied in this work. The synthetic index was called transparency level. When testing the associations between transparency levels and the three factors proposed, we found a strong positive association with healthcare systems $\left[\chi^{2}(1, N=60)=31.347, \varphi=.723, p<\right.$ $.05]$, which suggests a closer association between public healthcare systems and higher transparency levels.

However, the empirical evidence is inconclusive in terms of internet access $\left[\chi^{2}(1, N=60)=1.009, \varphi=-.130, p>.05\right]$ and administration levels or scales $\left[\chi^{2}(1, N=60)=.050, \varphi=-.029, p>.05\right]$. According to the current data, these factors do not affect the concept of transparency implemented by the studied administrations. 
To test the predictive value of healthcare systems, we developed a binary logistic regression model with the dichotomous synthetic index of transparency level as a dependent variable. As no association was found between the synthetic index of transparency level and the other two factors, we excluded these from the model.

The binary logistic regression model was applied using the entry method. The omnibus test revealed a significant $\chi^{2}$ value $\left(\chi^{2}=36.885 ; p<.01\right)$, with an optimal Nagelkerke $R^{2}$ value of .618, achieving correct global classification of $85 \%$ of cases (Table 6).

Table 6. Binary logistic regression performed to predict the value of health systems and transparency level in Chile, Colombia, Ecuador, and Spain (2021)

\begin{tabular}{|l|c|c|c|c|c|c|}
\hline \multirow{2}{*}{ Variable } & \multirow{2}{*}{ B } & TE & Wald & $\boldsymbol{p}$ & \multicolumn{2}{|c|}{ OR } \\
\hline Health systems & -4.394 & 1.097 & 16.043 & 0.000 & 0.012 & 0.001 \\
\hline
\end{tabular}

The results described above rule out the predictive value of internet access and administration levels or scales for transparency level in this model, as described above based on the chi-squared association test. However, healthcare systems had a significant effect on the dependent variable $(O R=.011 ; p<0.01)$. In this case, it is important to note that this study category included public healthcare systems (1), represented by Ecuador and Spain, while the reference category comprised mixed public-private systems (0), represented by Chile and Colombia. The results presented in Table 4 confirm the prediction that the studied administrations within a public healthcare system will have a reduced likelihood of showing lower transparency levels. Specifically, the probability of showing lower transparency level is decreased by $91 \%$ for institutions (calculated using the OR results) within a public healthcare system. Therefore, and based on these results, $\mathrm{H} 1$ is confirmed, stating that: The type of healthcare system affects the level of transparency implemented on the websites of the healthcare divisions of the studied countries. However, we reject $\mathrm{H} 2$ and $\mathrm{H} 3$, which considered the influence of internet access and administration levels or scales on the transparency level of the studied public administrations.

Specifically, the probability of showing lower transparency level is decreased by $91 \%$ for institutions (calculated using the OR results) within a public healthcare system

\section{Discussion and conclusions}

The findings of this study will be interesting to policymakers, researchers, and practitioners. Corruption is a latent problem in developing countries (Muñoz-Lalinde; Molina-Rodríguez-Navas, 2020), and transparency can help to prevent this phenomenon (Hänska; Bauchowitz, 2019; Bertot; Jaeger; Grimes, 2010) and stimulate greater citizen participation (Schmidthuber; Ingrams; Hilgers, 2020) as well as administrative accountability (Grimmelikhuijsen; Welch, 2012; García-García; Curto-Rodríguez, 2018). Transparency depends on various factors such as citizens' demands and expectations (Canel-Crespo; Luoma-aho, 2019) and even the general configuration of the media system (Del-Rey-Morató, 2007; Oller-Alonso; Barredo-Ibáñez, 2013) or culture (Sagiv et al., 2017). We propose herein that there are three factors, i.e., healthcare systems, internet access, and administration levels or scales, that can affect the implementation of transparency by public healthcare administrations in the studied countries of Chile, Colombia, Ecuador, and Spain.

In this regard, evidence was provided by the significant associations found between each factor according to the chi-squared test. Administration levels or scales were only related with the fourth axis proposed for transparency, that is, accessibility and institutional data. This axis showed the lowest number of associations for the healthcare systems variable and was one of the least relevant for internet access. Almost half of the associations found for this synthetic variable (internet access) were related to the transparency of economic indicators, whose presence was more evident in countries with a technological gap (Colombia and Ecuador) than those with high internet access (Chile and Spain). However, the main associations were found in relation to healthcare systems, whether that be for economic indicators or aspects relating to staff and hiring.

However, we had to reject our hypotheses $\mathrm{H} 2$ and $\mathrm{H} 3$, with the empirical evidence supporting the null hypothesis, preventing the prediction of the transparency level using these factors. However, we must reject the null hypothesis for $\mathrm{H} 1$, so the key finding of this study is the evidence confirming the influence of public healthcare systems on transparency levels in the studied contexts. This finding is consistent with previous literature that confirms the existence of issues regarding information access in Chile (Binimelis-Espinoza; Veechi-Llanquile, 2018; Goyenechea, 2019) and Colombia (Bernal-Acevedo; Forero-Camacho, 2011; Patiño, 2013; Orduña-Ortegón, 2014). Conversely, efforts to increase transparency in Ecuador are demonstrated by the monitoring of compliance with the provisions of the normative framework (Ministerio de Salud Pública, 2016), as well as in Spain, where Act 19/2013 has encouraged adoption of transparency at different levels of management.

Despite the nonrandom sampling, this study has some implications. As stated in prior literature, transparency contributes to improving the efficiency of public administrations (Calvo-Gutiérrez, 2013) and stimulates democratic participation (Hänska; Bauchowitz, 2019). However, based on our predictions, if a public healthcare administration belongs to a 
public healthcare system, the likelihood of finding low transparency levels will be lower in 9 out of 10 cases. Consequently, although some discourses describe private or mixed (public-mixed) administrations as a potential source of greater separation from the State, increasing the objectivity of figures and procedures, the involvement of the State, at least in the healthcare field, enhances access to information by the community, and the State has a greater social responsibility for communicating the activities carried out by these institutions, as well as by whom and how. In summary, public administrations are predictors of improved access to significant facts and management planning, aspects that match the definition of transparency provided by García-García and Curto-Rodríguez (2018), whereas private or mixed administrations tend to conceal such information more frequently. Perhaps, one of the factors explaining this conclusion is related to the weakness, or even absence, of a general information system within one of these contexts, e.g., here in the case of Colombia (Bernal-Acevedo; Forero-Camacho, 2011; Patiño, 2013). If general information systems become more interlinked, the gaps emerging in the implementation of transparency can be minimized, hence more homogeneous levels can be established at the different administration levels or scales.

Clearly, the presence of a transparency indicator does not guarantee the transparency of a site per se. Rather, it is the use of that information, the way in which it is presented to and managed by citizens, that enables active transparency. This is one of the limitations of the current study and highlights a possible future line of research, i.e., qualitative analysis of the mechanisms that link society to these websites, something that we have considered only superficially herein. However, we do consider that countries with mixed systems should improve the monitoring of websites of administrations to reinforce confidence within their social context (Schmidthuber; Ingrams; Hilgers, 2020). In this regard, a second future research line emerges, i.e., the difference between the type of healthcare system of the institution and transparency and user satisfaction levels. At the same time, future studies should include a larger, or random, sample to confirm the results predicted in this work.

The current sample only considers the major administrations of the regions and municipalities of each country, so the results cannot be generalized to the other health administrations in these countries. Indeed, at smaller institutions, which have less economic and human resources available, these indicators may be dramatically reduced. Exactly this scarcity of resources may be responsible for a more superficial implementation of transparency. This line of research should be thoroughly examined in the future.

Although the four countries studied herein have characteristics that are useful for this empirical analysis, Spain shows greater economic development overall and should thus invest greater resources in institutional communication and particularly the transparency of health administrations. This variable should also be investigated in future research based on these conclusions.

\section{References}

Abusleme, Cesar (2020). "Why do governments further open data strategies? The cases of Mexico, Chile and Colombia". Revista estudios de políticas públicas, v. 6, n. 1, pp. 20-43.

https://doi.org/10.5354/0719-6296.2020.57804

Agudelo-Calderón, Carlos-Alberto; Cardona-Botero, Jaime; Ortega-Bolaños, Jesús; Robledo-Martínez, Rocío (2011). "Sistema de salud en Colombia: 20 años de logros y problemas". Ciência \& Saúde Coletiva, v. 16, n. 6, pp. $2817-2828$. https://doi.org/10.1590/s1413-81232011000600020

Alloa, Emmanuel; Thomä, Dieter (2018). Transparency, society and subjectivity. Critical perspectives. Cham: Palgrave Macmillan. ISBN: 9783319771618

https://doi.org/10.1007/978-3-319-77161-8

Alt, James E.; Lassen, David-Dreyer (2006). "Fiscal transparency, political parties, and debt in OECD countries". European economic review, v. 50, pp. 1403-1439.

https://doi.org/10.1016/j.euroecorev.2005.04.001

Anderson, Thomas-Barnebeck (2009). "E-government as an anti-corruption strategy". Information economics and policy, v. 21, pp. 201-210.

https://doi.org/10.1016/j.infoecopol.2008.11.003 
Aparici, Roberto; García-Marín, David (2018). "Prosumers and emirecs: Analysis of two confronted theories". Comunicar, v. 55, pp. 71-79.

https://doi.org/10.3916/C55-2018-07

Barredo-Ibáñez, Daniel (2015). "El análisis de contenido. Una introducción a la cuantificación de la realidad". Revista San Gregorio, v. 1, pp. 26-31.

https://revista.sangregorio.edu.ec/index.php/REVISTASANGREGORIO/article/view/113/67

Beltrán-Orenes, Pilar; Martínez-Pastor, Esther (2016). "Grado de cumplimiento de las leyes de transparencia, acceso y buen gobierno, y de reutilización de los datos de contratación de la Administración central española". El profesional de la información, v. 25, n. 4, pp. 557-567.

https://doi.org/10.3145/epi.2016.jul.05

Berganza-Conde, María-Rosa; Arcila-Calderón, Carlos; De-Miguel-Pascual, Roberto (2016). “Negativity in the political news in the Spanish news media". Revista latina de comunicación social, v. 71, pp. 160-178.

https://doi.org/10.4185/RLCS-2016-1089en

Bernal-Acevedo, Óscar; Forero-Camacho, Juan-Camilo (2011). "Sistemas de información en el sector salud en Colombia". Revista gerencia y políticas de salud, v. 10, n. 21, pp. 85-100.

https://doi.org/10.11144/Javeriana.rgsp10-21.siss

Bertot, John C.; Jaeger, Paul T.; Grimes, Justin M. (2010). “Using ICTs to create a culture of transparency: E-government and social media as openness and anti-corruption tools for societies". Government information quarterly, v. 27, pp. 264271. https://doi.org/10.1016/j.giq.2010.03.001

Bertot, John C.; Jaeger, Paul T.; Grimes, Justin M. (2012). "Promoting transparency and accountability through ICTs, social media, and collaborative e-government". Transforming government: People, process and policy, v. 6, n. 1, pp. 78-91. https://doi.org/10.1108/17506161211214831

Betancourt-Velázquez, Andrea-Carolina; Caviedes-Niño, Ivonne-Liliana (2018). “Metodología de correlación estadística de un sistema integrado de gestión de la calidad en el sector salud". Signos, v. 10, n. 2, pp. 119-139.

https://doi.org/10.15332/s2145-1389.2018.0002.07

Binimelis-Espinoza, Helder; Veechi-Llanquile, Valentina (2018). "Transparencia y accesibilidad: evaluación del Servicio Nacional de Discapacidad en Chile desde la perspectiva de personas en situación de discapacidad visual". Revista uruguaya de ciencia política, v. 27, n. 2, pp. 57-74.

https://doi.org/10.26851/rucp.28.1

Borge-Bravo, Rosa (2007). "Nuevas tecnologías y regeneración de la democracia”. In: Cotino-Hueso, Lorenzo (coord.). Democracia, participación y voto a través de las nuevas tecnologías. Granada: Comares, pp. 25-34. ISBN: 9788498362329

Buitrón-Vega, Miriam-Elena; Gea-Izquierdo, Enrique; García-Oquendo, María-Verónica (2016). “Tecnologías en información y comunicación sanitaria". Revista PUCE, v. 102, pp. 271-290.

https://doi.org/10.26807/revpuce.v0i102.15

Caamaño-Alegre, José; Lago-Peñas, Santiago; Reyes-Santias, Francisco; Santiago-Boubeta, Aurora (2011). “Budget transparency in local governments: An empirical analysis". Local government studies, v. 39, n. 2.

https://doi.org/10.1080/03003930.2012.693075

Calvo-Gutiérrez, Elvira (2013). “Comunicación política 2.0 y buen gobierno”. In: Römer-Pieretti, Max (coord.). Miradas a las pantallas en el bolsillo. Madrid: Universidad Camilo José Cela: Madrid, pp. 70-80. ISBN: 9788495891594

Cameron, Wayne (2004). "Public accountability: Effectiveness, equity, ethics". Australian journal of public administration, v. 63, n. 4, pp. 56-67.

https://doi.org/10.1111/j.1467-8500.2004.00402.x

Canel-Crespo, María-José; Luoma-aho, Vilma (2019). Public sector communication. Closing gaps between citizens and public organizations. Hoboken, NJ: Wiley-Blackwell. ISBN: 9781119135623

Carnicero, Javier; Rojas, David (2010). Application of information and communication technologies for health systems in Belgium, Denmark, Spain, the United Kingdom and Sweden. Santiago de Chile: United Nations. ISBN: 9789211217469

Casadesús-de-Mingo, Anahí; Cerrillo-Martínez, Agustí (2018). “Improving records management to promote transparency and prevent corruption". International journal of information management, v. 38, n. 1, pp. $256-261$.

https://doi.org/10.1016/j.ijinfomgt.2017.09.005

Charvel, Sofía; Cobo, Fernanda; Larrea, Silvana; Baglietto, Juliana (2018). “Challenges in priority setting from a legal perspective in Brazil, Costa Rica, Chile, and Mexico". Health and human rights journal, v. 20, n. 1, pp. $173-184$.

https://www.ncbi.nlm.nih.gov/pmc/articles/PMC6039745/ 
Cid, Camilo; Uthoff, Andras (2017). "The pending health reform in Chile: reflections on a proposal to transform the system". Revista panamericana de salud pública, v. 41.

https://doi.org/10.26633/RPSP.2017.170

Cuillier, David; Piotrowski, Suzzane J. (2009). "Internet information seeking and its relation to support for access to government records". Government information quarterly, v. 26, pp. 441-449.

https://doi.org/10.1016/j.giq.2009.03.001

Da-Cruz, Nuno-Ferreira; Marques, Rui-Cunha (2014). "Scorecards for sustainable local governments". Cities: The international journal of urban policy and planning, v. 39, pp. 165-170.

https://doi.org/doi:10.1016/j.cities.2014.01.001

Del-Rey-Morató, Javier (2007). Comunicación política, Internet y campañas electorales. De la Teledemocracia a la Ciberdemocracia. Madrid: Tecnos. ISBN: 9788430945061

Díaz, Leonardo (2015). “Administrando la comunicación de riesgos en una emergencia sanitaria, 'El caso de la erupción del Volcán Calbuco', Chile 2015". Revista española de comunicación en salud, v. 10, n. 1, pp. 94-101.

https://doi.org/10.20318/recs.2019.4443

Etzioni, Amitai (2010). "Is transparency the best disinfectant?". Journal of political philosophy, v. 18, pp. 389-404. https://doi.org/10.1111/j.1467-9760.2010.00366.x

Fenster, Mark (2015). "Transparency in search of a theory". European journal of social theory. v. 18, n. 2, pp. $150-167$. https://doi.org/10.1177/1368431014555257

Francescutti, Pablo; Saperas, Enric (2015). “Los gabinetes de prensa como fuente de información política en España”. La trama de la comunicación, v. 19, pp. 265-282.

https://doi.org/10.35305/lt.v19i0.526

Gandía, Juan L.; Marrahí, Lucía; Huguet, David (2016). "Digital transparency and Web 2.0 in Spanish city councils". Government information quarterly, v. 33, n. 1, pp. 28-39.

https://doi.org/10.1016/j.giq.2015.12.004

García-Altés, Anna; Argimon, Josep M. (2016). "La transparencia en la toma de decisiones de salud pública". Gaceta sanitaria, v. 30, Supl. 1, pp. 9-13.

https://doi.org/10.1016/j.gaceta.2016.05.005

García-García, Jesús; Curto-Rodríguez, Ricardo (2018). “Divulgación de información pública de las comunidades autónomas españolas (2013-2017): portal de datos abiertos, portal de transparencia y web institucional". El profesional de la información, v. 27, n. 5, pp. 1051-1060.

https://doi.org/10.3145/epi.2018.sep.09

García-García, Jesús; Curto-Rodríguez, Ricardo (2019). “Exercici de retre comptes mitjançant portals de dades obertes a les comunitats autònomes espanyoles". IDP Revista de internet, derecho y política, v. 29.

https://doi.org/10.7238/idp.v0i29.3182

Garriga-Portolà, Marc (2011). “¿Datos abiertos? Sí, pero de forma sostenible”. El profesional de la información, v. 20, n. 3, pp. 298-303.

https://doi.org/10.3145/epi.2011.may.08

Gértrudix, Manuel; Gertrudis-Casado, María-Carmen; Álvarez-García, Sergio (2016). "Consumption of public institutions' open data by Spanish citizens". El profesional de la información, v. 25, n. 4, pp. 535-544.

https://doi.org/10.3145/epi.2016.jul.03

González-Limón, Myriam; Rodríguez-Ramos, Asunción (2019). “Revisión del cumplimiento de los datos abiertos por los ayuntamientos españoles en la iniciativa Aporta”. Revista española de documentación científica, v. 42, n. 4, pp. $247-261$. https://doi.org/10.3989/redc.2019.4.1605

Goyenechea, Matías (2019). "Estado subsidiario, segmentación y desigualdad en el sistema de salud chileno". Cuadernos médico sociales, v. 59, n. 2, pp. 7-12.

https://www.celag.org/chile-estado-subsidiario-y-colapso-del-sistema-sanitario/

Grimmelikhuijsen, Stephan G.; Welch, Eric W. (2012). "Developing and testing a theoretical framework for computer-mediated transparency of local governments". Public administration review, n. 72, pp. 562-571.

https://doi.org/10.1111/j.1540-6210.2011.02532.x

Hänska, Max; Bauchowitz, Stefan (2019). “Can social media facilitate a European public sphere? Transnational communication and the Europeanization of Twitter during the Eurozone crisis". Social media + society, v. 5, n. 3.

https://doi.org/10.1177/2056305119854686 
Hernández-Bonivento, José (2020). “La forma y la esencia: efectos de las leyes de transparencia, acceso a la información y participación ciudadana en la gobernanza democrática local en Chile”. Revista de gestión pública, v. 7, n. 2, pp. 143-169. https://doi.org/10.22370/rgp.2018.7.2.2193

Human Rights Watch (2020). Human rights dimensions of Covid-19 response.

https://bit.ly/3qRe7II

Humprecht, Edda (2020). "How do they debunk "fake news"? A cross-national comparison of transparency in fact checks". Digital journalism, v. 8, n. 3, pp. 310-327.

https://doi.org/10.1080/21670811.2019.1691031

Jaeger, Paul T.; Bertot, John-Carlo (2010). "Transparency and technological change: Ensuring equal and sustained public access to government information". Government information quarterly, v. 27, pp. 371-376.

https://doi.org/10.1016/j.giq.2010.05.003

Kim, Soonhee; Lee, Jooho (2012). "E-participation, transparency, and trust in local government". Public administration review, v. 72, n. 6, pp. 819-828.

https://doi.org/10.1111/j.1540-6210.2012.02593.x

Lucio, Ruth; Villacrés, Nilhda; Henríquez, Rodrigo (2011). "Sistema de salud de Ecuador". Salud pública de México, v. 53, n. 2, pp. 177-187.

https://www.redalyc.org/articulo.oa?id=10619779013

Magallón-Rosa, Raúl; Bolaños-Huertas, Victoria; Anderica-Caffarena, Victoria (2017). “Changing civil society in Spain through transparency and civic technologies". Observatorio (OBS), v. 11, n. 3, pp. 61-77.

https://doi.org/10.15847/obsOBS1132017969

Manfredi-Sánchez, Juan-Luis (2017). "Indicadores de transparencia y buen gobierno de las webs municipales españolas". Estudios sobre el mensaje periodístico, v. 23, n. 1, pp. 477-488.

https://doi.org/10.5209/ESMP.55608

Masud, Abdul-Kaium; Bae, Seong-Mi; Manzanares, Javier; Kim, Jong-Dae (2019). “Board directors' expertise and corporate corruption disclosure: The moderating role of political connections". Sustainability, v. 11, n. 16, pp. 4491. https://doi.org/10.3390/su11164491

Medranda-Morales, Narcisa-Jessenia (2017). Calidad y transparencia en la información y comunicación que se emite a través de las páginas webs de los municipios: comparación de caso Ecuador y España. Barcelona: Universitat Autònoma de Barcelona.

http://hdl.handle.net/10803/458654

Ministerio de Salud Pública (2016). Municipios saludables en el Ecuador [Health municipalities in Ecuador]. Quito: Asociación de Municipalidades Ecuatorianas.

Molina-Guzmán, Adriano (2018). "Funcionamiento y gobernanza del Sistema Nacional de Salud del Ecuador". Íconos. Revista de ciencias sociales, v. 63, pp. 185-205.

https://doi.org/10.17141/iconos.63.2019.3070

Molina-Rodríguez-Navas, Pedro; Medranda-Morales, Narcisa-Jesenia (2018). "La transparencia de los municipios de Ecuador en sus sitios web: metodología y resultados". América Latina hoy, v. 80, pp. 143-169. http://doi.org/10.14201/alh201880143169

Molina-Rodríguez-Navas, Pedro; Simelio-Solà, Núria; Corcoy-Rius, Marta (2017). “Methodology for transparency evaluation: procedures and problems". Revista latina de comunicación social, v. 72, pp. 818-831.

https://doi.org/10.4185/RLCS-2017-1194en

Molina-Rodríguez-Navas, Pedro; Simelio-Solà, Núria; Corcoy-Rius, Marta; Aguilar-Pérez, Antonio (2015). “Mapa Infoparticipa: cartografía interactiva para la mejora de la calidad y la transparencia de la comunicación pública local”. Ar@ cne. Revista electrónica de recursos en internet sobre geografía y ciencias sociales, v. 202.

http://www.ub.es/geocrit/aracne/aracne-202.pdf

Moreno-Sardà, Amparo; Molina-Rodríguez-Navas, Pedro; Corcoy-Rius, Marta (2013). "The information published by local governments. The websites of Catalonia's municipal governments". Revista latina de comunicación social, v. $68, \mathrm{pp}$. 502-528.

https://doi.org/10.4185/RLCS-2013-987/CrossRef link

Moreno-Sardà, Amparo; Molina-Rodríguez-Navas, Pedro; Simelio-Solà, Núria (2017). "The impact of legislation on the transparency in information published by local administrations" El profesional de la información, v. 26, n. 3, pp. 370-380. https://doi.org/10.3145/epi.2017.may.03 
Muñoz-Lalinde, Johamna; Molina-Rodríguez-Navas, Pedro (2020). “Metodología para evaluar la transparencia en las páginas web de las alcaldías colombianas". RISTI. Revista ibérica de sistemas y tecnologías de la información, v. E35, pp. 422-435.

http://risti.xyz/issues/ristie35.pdf

Oller-Alonso, Martín; Barredo-Ibáñez, Daniel (2013). Intermediate journalism cultures. International comparative studies in journalism. Medijska istraživanja, v. 19, n. 1, pp. 39-60.

https://repository.urosario.edu.co/handle/10336/27896

Orduña-Ortegón, Yeimi-Pilar (2014). "Avances en la construcción de un sistema de información en salud en Colombia". Ciencia y tecnología para la salud visual y ocular, v. 12, n. 2, pp. 73-86.

https://doi.org/10.19052/sv.3297

Patiño, José-Félix (2013). "The health system in Colombia: crisis without precedent". Revista de cirugía, v. 28, n. 4, pp. 259-261.

https://encolombia.com/medicina/revistas-medicas/cirugia/vol-2804/sistema-salud

Pina, Vicente; Torres, Lourdes; Royo, Sonia (2010). "Is e-government promoting convergence towards more accountable local governments?". International public management journal, n. 13, v. 4, pp. 350-380.

https://doi:10.1080/10967494.2010.524834

Rebolledo, Marta; Rodríguez-Virgili, Jordi; Zamora-Medina, Rocío (2015). “La comunicación pública y local: transparencia y participación. Análisis comparativo de las websites municipales de Navarra y Murcia". In: XII Congreso español de ciencia política y de la administración - AECPA.

https://aecpa.es/es-es/la-comunicacion-publica-local-transparencia-y-participacion/congress-papers/1529

Riego-Ramírez, Cristián (2019). "Conflict resolution in the health system, mediation and arbitration in an institutional context". Revista chilena de derecho privado, v. 33, pp. 43-72.

https://doi.org/10.4067/s0718-80722019000100043

Rivero-Menéndez, José-Ángel; Mora-Agudo, Leonor; Flores-Ureba, Sandra (2007). "Un estudio de la rendición de cuentas a través del e-gobierno en la administración local Española". In: Empresa global y mercados locales: XXI Congreso Anual AEDEM.

Roberts, Alasdair (2006). Blacked out: Government secrecy in the information age. New York: Cambridge University Press. ISBN: 9780521731546

Rotarou, Elena S.; Sakeriallou, Dikaios (2017). "Neoliberal reforms in health care systems and the construction of long-lasting inequalities in health care: A case study from Chile". Health policy, v. 121, n. 5, pp. 495-503.

https://doi.org/10.1016/j.healthpol.2017.03.005

Sagiv, Lilach; Roccas, Sonia; Cieciuch, Jan; Schwartz, Shalom H. (2017). "Personal values in human life". Nature human behaviour, v. 1, n. 9, pp. 630-639.

https://doi.org/10.1038/s41562-017-0185-3

Sanders, Karen; Canel-Crespo, María-José; Holtz-Bacha, Christina (2011). "Governments: A three-country comparison of how governments communicate with citizens". The international journal of press/politics, v. 16, n. 4, pp. 523-547. https://doi.org/10.1177/1940161211418225

Santos, Paloma-María; Galindo, Fernando; Rover, Aires-José (2019). “Acceso democrático a la información en los portales del gobierno español: un análisis comparativo entre los años de 2013 y 2015”. Ibersid, v. 13, n. 2, pp. 13-20.

https://www.ibersid.eu/ojs/index.php/ibersid/article/view/4502

Schmidthuber, Lisa; Ingrams, Alex; Hilgers, Dennis (2020). "Government openness and public trust: The mediating role of democratic capacity". Public administration review, v. 81, n. 1, pp. 91-109.

https://doi.org/10.1111/puar.13298

Schudson, Michael (2020). "The shortcomings of transparency for democracy". American behavioral scientist, v. 64, n. 11, pp. 1670-1678. https://doi.org/10.1177/0002764220945347

Skaržauskienè, Aelita; Mačiulienè, Monika (2020). "Mapping international civic technologies platforms". Informatics, v. 7, n. 4, 46.

https://doi.org/10.3390/informatics 7040046

Suárez-Rozo, Luisa-Fernanda; Puerto-García, Stephanie; Rodríguez-Moreno, Lina-María; Ramírez-Moreno, Jaime (2017). "La crisis del sistema de salud colombiano: una aproximación desde la legitimidad y la regulación". Revista gerencia y políticas de salud, v. 16, n. 32, pp. 34-50.

http://doi.org/10.11144/javeriana.rgps16-32.cssc 
Uvalle-Berrones, Ricardo (2007). “Gobernabilidad, transparencia y reconstrucción del Estado”. Convergencia, v. 14, n. 45, pp. 47-74.

https://bit.ly/3iwPj5Y

Van-Ruler, Betteke (2018). "Communication theory: An underrated pillar on which strategic communication rests". International journal of strategic communication, v. 12, n. 4, pp. 367-381.

https://doi.org/10.1080/1553118X.2018.1452240

Vargas-Arias, Luis-Humberto (2019). Límites a la autonomía de los Gobiernos Autónomos Descentralizados. Estudio de los GAD parroquiales rurales. Ecuador: Universidad Andina Simón Bolívar.

https://repositorio.uasb.edu.ec/handle/10644/6694

Vian, Taryn (2020). "Anti-corruption, transparency and accountability in health: concepts, frameworks, and approaches". Global health action, v. 13, sup. 1.

https://doi.org/10.1080/16549716.2019.1694744

Vu, Hong Tien; Saldaña, Magdalena (2021). “Chillin' effects of fake news: Changes in practices related to accountability and transparency in American newsrooms under the influence of misinformation and accusations against the news media". Journalism \& mass communication quarterly, v. 98, n. 3, pp. 769-799.

https://doi.org/10.1177/1077699020984781

We Are Social (2020a). Digital 2020: Global digital yearbook.

https://datareportal.com/reports/digital-2020-global-digital-yearbook

We Are Social (2020b). Digital 2020: Ecuador.

https://datareportal.com/reports/digital-2020-ecuador

We Are Social (2021). Digital 2021: Global overview report.

https://wearesocial.com/digital-2021

World Bank (2020). GDP per capita (current US\$).

https://data.worldbank.org/indicator/NY.GDP.PCAP.CD

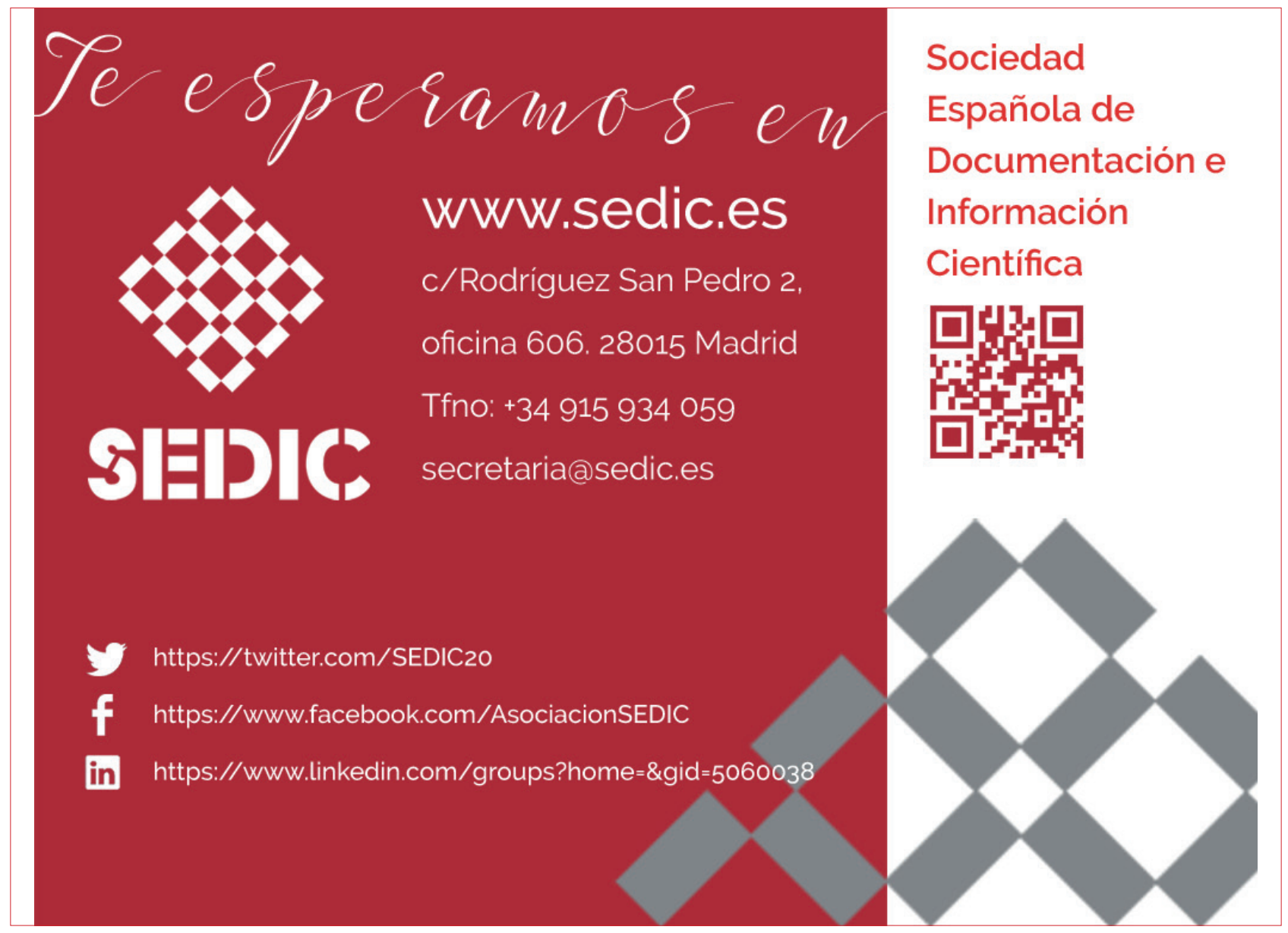

